\title{
THE GENESIS AND MOVEMENT OF CAPITALS OF THE ROMAN CATHOLIC CLERICAL COLLEGIUM OF THE RUSSIAN EMPIRE
}

\author{
Andrey I. Ganchar \\ Grodno State Agrarian University, Grodno, Republic of Belarus
}

\begin{abstract}
The aim of managing monetary capitals, owned by the Roman Catholic Church in the Russian Empire, required taking a number of measures on their accumulation in Roman Catholic Clerical Collegium. The organization owned several capitals: auxiliary capital of the Roman Catholic clergy of the Russian Empire; auxiliary capital of the Roman Catholic clergy of the Kingdom of Poland; donation capital belonging to individual spiritual institutions; renovation capital; residual equity from alimenting the Roman Catholic clergy in the colonies of settlers-owners of the Samara and the Saratov provinces.

The article is based on the materials of the Russian state historical archive (Saint Petersburg), Manuscript Department of the library of the Academy of Sciences of Lithuania (Vilnius), as well as on legislative acts of the Russian Empire, which regulated the financial relations in the Roman Catholic Church.

Studying the practice of capital management by the Roman Catholic Church shows a dual regulation of cash flow from the government and the Roman Catholic Clerical Collegium that led to financial losses. Regardless of the purposes of higher secular and theological administration of Roman Catholic Church, the measures on reforming the system of capital management by the Roman Catholic Church in the Russian Empire allowed for preserving these capitals in the course of social events of the first third of the $20^{\text {th }}$ century.

Key words: The Roman Catholic Church, the Russian Empire, the Roman-Catholic Clerical Collegium, capitals, the $19^{\text {th }}$ century, beginning of the $20^{\text {th }}$ century.

Citation. Ganchar A.I. The Genesis and Movement of Capitals of the Roman Catholic Clerical Collegium of the Russian Empire. Vestnik Volgogradskogo gosudarstvennogo universiteta. Seriya 4, Istoriya. Regionovedenie. Mezhdunarodnye otnosheniya [Science Journal of Volgograd State University. History. Area Studies. International Relations], 2018, vol. 23, no. 2, pp. 111-126. (in Russian). DOI: https://doi.org/10.15688/jvolsu4.2018.2.9
\end{abstract}

\section{ВОЗНИКНОВЕНИЕ И ДВИЖЕНИЕ КАПИТАЛОВ, СОСТОЯВШИХ В ВЕДЕНИИ РИМСКО-КАТОЛИЧЕСКОЙ ДУХОВНОЙ КОЛЛЕГИИ РОССИЙСКОЙ ИМПЕРИИ}

\author{
Андрей Иванович Ганчар \\ Гродненский государственный аграрный университет, г. Гродно, Республика Беларусь
}


ков Самарской и Саратовской губерний. Независимо от целей высшей светской и духовной администрации, проведенные действия по реформированию системы управления капиталами Римско-католической церкви в Российской империи позволили сохранить их в ходе произошедших в первой трети XX в. изменений в жизни общества.

Ключевые слова: Римско-католическая церковь, Российская империя, римско-католическая духовная коллегия, капиталы, XIX век, начало XX века.

Цитирование. Ганчар А. И. Возникновение и движение капиталов, состоявших в ведении Римско-католической духовной коллегии Российской империи // Вестник Волгоградского государственного университета. Серия 4, История. Регионоведение. Международные отношения. - 2018. - Т. 23, № 2. - С. 111-126. - DOI: https://doi.org/10.15688/jvolsu4.2018.2.9

В исторической литературе по проблеме обращения капиталов, принадлежавших Римско-католической церкви (далее - РКЦ) в Российской империи, содержатся лишь некоторые фрагментарные сведения $[2 ; 4 ; 5 ; 13$ 15; 19-27]. Пожалуй, это объясняется как сложностью выявления архивных документов, так и отсутствием должного интереса к избранной автором данной статьи теме. Например, А.К. Тихонов, Р.В. Зенюк хотя и отметили введение государственного контроля в отношении финансов Римско-католической церкви в Российской империи еще Екатериной II, далее эту тему не развивали $[4$, с. $99 ; 13$, с. 79 80]. Польский исследователь Р. Стопиковский, опираясь на публикации в газетах «Przegląd Katolicki», «Tygodnik Katolicki» периода второй половины XIX - начала XX в., привел ряд фактов в отношении финансирования ремонта и строительства лишь отдельных р.-к. храмов в Российской империи [26, s. 122-141].

В данной статье впервые в отечественной и зарубежной историографии рассматриваются действия светской и духовной администрации РКЦ по аккумулированию и управлению капиталами, принадлежавшими РКЦ в Российской империи. Особое внимание уделено формам трансформации капиталов, их сохранению и расходованию. Следует также отметить, что ввиду специфичности положения по-иезуитских имений, а также выведения их из-под юрисдикции РКЦ в Российской империи, данная группа доходов в статье не рассматривается.

\section{Вспомогательный капитал р.-к. духовенства Российской империи}

В начале XIX в. митрополит всех р.-к. церквей в России Станислав Богуш-Сестран- цевич представил министру внутренних дел и народного просвещения А.Н. Голицыну доклад о необходимости установки от избытков доходов некоторых монастырей и р.-к. церквей общего капитала, проценты от которого могли бы идти на удовлетворение некоторых нужд р.-к. церквей и монастырей. На это, по докладу действительного тайного советника князя А.Н. Голицына, последовало высочайшее соизволение, объявленное им р.-к. духовной коллегии (далее - РКДК) 18 января 1820 года. В исполнение указанного высочайшего повеления, постановлением РКДК от 11 августа 1822 г., для образования общего вспомогательного капитала, согласно с заключением митрополита С. Сестранцевича, с 1 января 1823 г. были установлены складки с белого духовенства р.-к. епархий: Могилевской - 300 руб., Виленской - 1000 руб., Тельшевской - 600 руб., Луцкой - 450 руб., Каменецкой и Минской - по 112 руб. 50 коп., итого - 2575 руб.; и согласно высочайшему повелению Пр. Сената от 26 ноября 1822 г., с имений виленского кафедрального капитула (из имений, записанных виленским р.-к. епископом Войной на альтарию ${ }^{1}$ в виленском р.-к. кафедральном соборе, насчитывавших более 800 душ) - 3000 руб. в год ${ }^{2}$. К платежу установленных с белого духовенства складок, по указанному постановлению РКДК, были привлечены и епископы, получавшие содержание из недвижимых имений, а также капитулы, имевшие недвижимые имения. С установлением указанной складки с белого духовенства, монастыри не были привлечены к ней, так как они с давнего времени обязаны были вносить на содержание Главной семинарии при Виленском университете до 15000 руб. в год. Таким образом, сбор для вспомогательного капитала составил 5575 руб. се- 
ребром в год. Начался он с 1 января 1823 г. и поступал в два срока в Государственный заемный банк и в Государственный коммерческий банк [7, № 2892].

Из донесения РКДК на имя министра народного просвещения главноуправляющего духовными делами иностранных исповеданий видно, что 6 января 1826 г. налицо вспомогательного капитала было 18080 руб. 77 коп. (63 282 руб. 72 $\frac{1}{2}$ коп. ассигнациями), а в феврале 1828 г. - 34789 руб. 43 коп. (121 763 руб. 92 $\frac{1}{2}$ коп. ассигнациями). Впоследствии было разрешено обращать в вспомогательный капитал доходы от всех праздных бенефиций и часть процентов и других взысканий, определенных по тяжебным делам духовенства с частными лицами. По состоянию на апрель 1829 г. в Государственном заемном банке накопилось вспомогательного капитала с процентами 147403 руб. $82 \frac{1}{2}$ коп. ассигнациями, а в Государственном коммерческом банке - 268 руб. серебром, также с процентами.

При самом учреждении вспомогательного капитала положено было, чтобы он оставался неприкосновенным, и чтобы только проценты были назначаемы на вспоможение или ссуду. С целью усиления капитала, РКДК до 1828-1829 гг. не производила никаких выдач из вспомогательного капитала (кроме лишь для трех р.-к. церквей в Луцкой р.-к. епархии, которым понадобилось вспоможение и которым с разрешения Главного управления духовных дел иностранных исповеданий производилось на их содержание с 1828 г. не более 900 руб. в год) и проценты с него присоединялись к капиталу.

Между тем РКДК поручено было войти в рассмотрение и представить мнение о правилах для назначения в необходимых случаях вспоможений или временных ссуд духовенству РКЦ из вспомогательного капитала. В 1829 г., на основании сведений и мнений, представленных начальниками р.-к. епархий, РКДК были составлены правила о порядке заведывания вспомогательным капиталом:

1) поскольку фундуши ${ }^{3}$ и нужды р.-к. епархий были не равны, да и вспомогательный капитал состоял не только из одних складок, то надлежало делать пособие из общего капитала с тем условием, чтобы при равных нуждах двух епархий преимущество имела та, которая вносила более сумм на составление капитала;

2) поскольку вспомогательный капитал был еще незначителен, то до увеличения его не следовало делать расходов без крайней необходимости;

3) чтобы отклонять излишние требования о вспоможении, ни в каком случае не стоило давать его р.-к. церкви, в которой священник получал не более 200 руб. серебром годового дохода и церковь зависела от светского ктитора, который и был обязан заботиться о ее благосостоянии;

4) при каждом требовании пособия из вспомогательного капитала, РКДК обязывалась производить разыскание и постановления свои предоставлять на рассмотрение Главному управлению духовных дел иностранных исповеданий (далее - ДДИИ);

5) требования р.-к. епархий о пособии из вспомогательного капитала стараться ограничивать внесенными ими складками в его состав и тем самым побуждать их к увеличению своих складок;

6) производимое пособие 900 руб. ассигнациями ежегодно для трех р.-к. церквей Луцкой епархии отнести на счет капитала этой епархии, отделив из последнего на этот предмет 18000 руб. в особый билет, остальной же за тем капитал весь соединить в один билет.

Соглашаясь с мнением РКДК, князь А.Н. Голицын, состоя в должности главноуправляющего духовными делами иностранных исповеданий, признавал еще нужным изыскать средства для усиления вспомогательного капитала, так как посредством его открывались способы к лучшему устройству р.-к. духовных семинарий, к поддержанию богоугодных заведений при р.-к. церквях и монастырях и к учреждению приходских училищ. Способы усилить вспомогательный капитал князю А.Н. Голицыну представлялись следующими:

1) поставить в обязанность р.-к. епархиальным начальствам поощрять подведомственное им духовенство к посильным вкладам, особенно тех, которые имели не одну бенефицию ${ }^{4}$;

2) обращать доходы от всех праздных бенефиций, отдаваемых во временную администрацию, до замещения последних; 
3) обращать часть процентов и других взысканий, определяемых по тяжебным делам р.-к. духовенства с частными лицами о неплатеже за несколько лет процентов с обеспеченных на имениях их монастырских и церковных капиталов, или о присвоении собственности р.-к. церквей и монастырей, причем начальники губерний, по согласованию с р.-к. епископами, могли определять долю, вносимую во вспомогательный капитал;

4) все доходы фундушей таких духовных мест, которые или по упадку их, или по бесполезности при изменившихся от времени отношениях и обстоятельствах могли быть упразднены, также должны принадлежать вспомогательному капиталу; если к данным фундушам принадлежали недвижимые имения, то их или отдавать в аренду порядком, установленным для казенных имений, или продавать с публичных торгов.

В рассуждении управления и употребления вспомогательного капитала князь Голицын полагал постановить еще следующие главные правила:

1) вспомогательный капитал состоит в ведении РКДК и Главного управления ДДИИ; РКДК хранит все билеты Государственного казначейства (далее - ГК) на данный капитал; разные вклады в вспомогательный капитал соединяются каждые три года в один капитал;

2) выдачи определяются р.-к. церквям и монастырям или навсегда, для содержания их с полезными при них заведениями, или во временное вспоможение, или в виде ссуды таким р.-к. монастырям и церквям, которые, имея не скудные фундуши, могут нуждаться в ссуде по случаю пожаров, неурожаев в их имениях и других временных, не терпящих отлагательства и требующих значительных издержек, нужд;

3) постоянные выдачи назначаются в РКДК один раз в год в декабре месяце и по рассмотрении данного назначения в Главном управлении ДДИИ вносятся в Комитет министров Российской империи на высочайшее утверждение;

4) временные выдачи в непредвиденных важных случаях назначаются РКДК немедленно; если они не превышают 3000 руб., то разрешаются Главным управлением ДДИИ; свы- ше данной суммы - Главное управление ДДИИ представляет на высочайшее усмотрение.

Духовенство, испрашивая у своего начальства пособия из вспомогательного капитала, во всех тех случаях, которые могли быть известны губернскому начальству, как-то в случае пожаров, неурожаев, прекращения по тяжбам или конкурсам пользования капиталами или недвижимым имением, с которых р.-к. духовенство до того получало содержание, должно было испрашивать и у губернского начальства засвидетельствования с его стороны перед Главным управлением ДДИИ.

Эти правила, по всеподданнейшему докладу главноуправляющего ДДИИ, император 21 апреля 1829 г. высочайше утвердить соизволил и пожаловал для усиления указанного капитала, на счет вторых по-иезуитских имений, 100000 руб., с отпуском этих денег из ГК в два срока в течение 1829 и 1830 годов. 28 мая 1829 г. были посланы соответствующие указы в РКДК главноуправляющему ДДИИ, начальникам губерний и в губернские правления присоединенных от Польши губерний, а также министру финансов [7, № 2892].

В 1832 г. последовало высочайшее повеление об упразднении некоторых р.-к. монастырей в Российской империи (предложение министра внутренних дел на имя РКДК, от 6 августа 1832 г. за № 1547), причем высочайше повелено было денежные капиталы, принадлежавшие упраздненным монастырям, присоединить к общему вспомогательному капиталу р.-к. духовенства. По состоянию на начало ноября 1832 г. вспомогательный капитал р.-к. духовенства простирался до 350000 руб. ассигнациями. С присоединением же к нему капиталов упраздненных монастырей, МВД полагало увеличение этой суммы до 4850000 рублей [9, № 5506].

Из сведений, представленных РКДК в Д乙ДИИ 22 декабря 1837 г. за № 3058, видно, что в 1837 г. вспомогательный капитал р.-к. духовенства Росийской империи состоял в билетах Коммерческого и Заемного банков, Комиссии погашения долгов и приказов общественного призрения в следующей сумме: из складок белого духовенства - 178989 руб. 10 коп.; упраздненных монастырей - 254845 руб. 68 коп.; всего серебром 433834 руб. 78 коп. К 1 января 1842 г., то есть ко времени секуляризации ду- 
ховных имуществ (высочайший указ от 1 января 1842 г.), вспомогательный капитал р.-к. духовенства состоял в сумме 1576214 рублей. Собственно же складочный капитал ${ }^{5}$ в общем вспомогательном капитале ко времени прекращения складок (1843 г.) достиг суммы 240485 руб. 42 коп. (журнал заседания РКДК от 7 апреля 1842 г.).

В 40-х гг. ХІХ в. последовала секуляризация имуществ сначала высшего, а затем и приходского р.-к. духовенства в Западном крае Российской империи, причем правительство, приняв в ведение казны населенные имения, отчислило в казну часть долговых обязательств р.-к. церквям на сумму, проценты с которой, в сложности с доходами с имений, были достаточны на покрытие штатного содержания, назначенного р.-к. духовенству Западного края.

Высочайшим повелением, от 26 марта 1843 г., все остатки от сосредоточенных капиталов передавались в РКДК для приобщения к вспомогательному капиталу р.-к. духовенства империи. На основании указанного высочайшего повеления, при предложении министра внутренних дел, от 7 апреля 1843 г. за № 1088, в РКДК поступило билетами Государственного заемного банка около 600000 рублей.

Высочайшее повеление о сосредоточении капиталов р.-к. духовенства было распространено министерством внутренних дел (далее - МВД) на аннуаты ${ }^{6}$, как денежные, так и вещественные, не на точном основании указов о капиталах духовенства, а по соображению с этими указами. Такое распространение на аннуаты меры, высочайше одобренной для капиталов духовенства, хотя, по мнению министра внутренних дел, подавшего 23 августа 1861 г. соответствующую записку в Комитет министров, и могло быть оправдано необходимостью возмещения расходов казны на содержание р.-к. духовенства и более уравнительного распределения сумм между всеми приходами и духовными учреждениями, но, тем не менее, изъятие аннуат из пользования тех учреждений, для которых они были завещены или записаны, послужило поводом ко многим спорам и жалобам. В тех случаях, когда в основных актах, по которым были записаны аннуаты, именно было сказано, что таковые предоставляются только в пользу известного монастыря или р.-к. церкви, под условием ежегодного отправления за упокой завещателя определенного количества богослужений и с оговоркой, что в случае упразднения монастыря или о.-к. церкви, или прекращения условленных служб, аннуата прекращалась. Помещики же имели полное юридическое основание в этих случаях не выплачивать аннуатных платежей.

Споры и тяжбы при взыскании аннуат преимущественно встречались относительно вещественных аннуат. Получение аннуат натурой, при пользовании им на месте непосредственно самим духовенством, оказалось очень неудобным при причислении таковых аннуат к общему вспомогательному капиталу р.-к. духовенства. Потому их взыскание требовало предварительного переложения их на деньги. Таким образом МВД отступило от точного смысла основных записей не только в отношении к назначению аннуат, но и в отношении к самому виду и способу их взимания, так как требовались деньги там, где были завещены произведения, причем ни духовным учреждениям, ни владельцам имений не было предоставлено фундаторами право заменять их денежным взносом. От этого произошли уклонения и споры, вследствие которых нельзя было избегнуть частых отсуждений аннуат судебными местами. Все эти тяжбы вовлекали губернские начальства и МВД в многочисленную переписку. Поэтому прекращение понудительных мер к переложению вещественных аннуат на деньги, предоставление тех из вещественных аннуат, которые до этого времени еще не были переложены на деньги, в непосредственное распоряжение тех учреждений, в пользу которых они были записаны, и сложение тех, не взысканных еще вещественных аннуат, которые были записаны в пользу упраздненных учреждений, без сомнения, по мнению министра внутренних дел П.А. Валуева (23 апреля 1861 г. - 9 марта 1868 г.), произвело бы благотворное впечатление как на духовенство, так и вообще на местных жителей и избавило бы правительственные и судебные места от огромной и часто бесполезной переписки.

С другой стороны, сумма вещественных аннуат, еще не переложенных на деньги (всего 18520 руб. 64 коп., считая и те аннуаты, на переложение которых помещики уже изъяви- 
ли согласие), была не так значительна в сравнении с вспомогательным капиталом, к которому они должны бы быть причислены (более 1,5 млн руб., не считая наросших процентов), чтобы пожертвование этой ежегодной суммой могло бы поставить в затруднение относительно покрытия расходов по содержанию р.-к. духовенства. Но как закон не должен иметь обратного действия, то само собой разумелось, что указанная выше мера нисколько не должна была касаться тех вещественных аннуат, которые уже были переложены окончательно на деньги и которые уже взыскивались бесспорно в пользу вспомогательного р.-к. капитала или которые уже были капитализированы.

П.А. Валуев на том же основании считал необходимым устранить всякий предлог к притязаниям на поступившие уже, вследствие прежних мер, и получившие назначения денежные аннуаты, взысканные капитальными суммами или взыскиваемые ежегодными платежами. В этих видах следовало бы, оставив вообще в прежней силе распоряжения, относящиеся к взысканию денежных аннуат и переложенных на деньги вещественных аннуат, предоставить только МВД прекращать взыскание таковых аннуат в тех собственно случаях, когда против них предъявлены споры, имевшие достаточное юридическое основание. Этим способом, по заверению министра внутренних дел, правительство, отказываясь от не имевших вполне законной силы притязаний, избежало бы продолжения многих тяжб, которые в противном случае всетаки могли бы окончиться сложением аннуат судебным порядком.

10 октября 1861 г. император Александр II утвердил соответствующее положение Комитета министров, вобравшее в себя предложения П.А. Валуева. МВД, по соглашению с духовным начальством, было предоставлено право слагать аннуаты, по которым еще не было ничего взыскано и которые были оспорены по причине неисполнения определенных фундаторами условий, если, по каким-либо причинам, условия эти не могли быть впредь исполняемы [20, № 37473].

Высочайше утвержденным журналом Комитета по делам РКЦ - от 29 февраля, 8 и 14 марта 1856 г. - и высочайше утвержден- ным мнением Государственного Совета - от 28 мая 1862 г. - было установлено, чтобы в состав вспомогательного капитала поступали и остатки от суммы в 578791 руб., ассигнуемых ежегодно из казны по смете МВД на содержание р.-к. духовенства Западных губерний Российской империи [19, № 38323]. В ведение РКДК, для указанной цели, поступили и все остальные претензии в виде аннуат и долгов, числившихся на имениях, годовые платежи по которым, по состоянию на 1 июня 1908 г. составлявшие от 4 до 5 тыс. руб., зачислялись в состав доходов от вспомогательного капитала. В некоторых же случаях погашались и сами капиталы, зачисляемые в состав вспомогательного капитала. Часть долгов и аннуат, денежных и вещественных (сельскохозяйственные продукты), перешедших в ведение РКДК с 1 мая 1842 г. (денежные) и с 1 мая 1844 г. (вещественные), за давностью и отсутствием документов оказались к поступлению безнадежными и были исключены из долговых книг. За передачей подуховных имений в ведение казны, складки в вспомогательный капитал были прекращены в 1843 г. (предложение министра внутренних дел от 26 мая 1843 г. за № 1598) [3, л. 223-225].

В 1864 г. вспомогательный капитал р.-к. духовенства Российской империи, за последовавшими в состав его поступлениями, достиг суммы 2122971 руб., в том числе по кассовой книге РКДК числилось 1692971 рублей. В ремонтный капитал было перечислено 300000 руб. и числилось в долгу к 1864 г. 130000 руб. по займам, выданным в разное время из сумм РКДК, с надлежащего разрешения, в размере 725000 руб., которые в свое время были возвращены РКДК с процентами.

Дальнейшее увеличение вспомогательного капитала находилось в зависимости от следующих факторов: от размера остатков от сумм отпускаемых из казны на содержание р.к. духовенства по смете МВД, от поступления сумм на полное погашение долгов и капитализации аннуат и от остатков по сметам РКДК из процентов от вспомогательного капитала.

В течение всего периода времени заведывания РКДК вспомогательным капиталом p.-к. духовенства Российской империи на счет указанного капитала были произведены следующие расходы: в 1842 г. на покупку дома 
бывшей российской академии под помещение переведенной из г. Вильно р.-к. духовной академии (далее - РКДА) - 70000 руб.; в 1842 г. на перестройку указанного дома под помещение РКДА - 168830 руб.; в 1867 г. на приобретение для РКДА смежного с нею дома полковницы Бекетковской - 55000 руб.; в 1874 г. на приспособление указанного дома под помещение РКДА - 14000 руб.; в 1846 г. на покупку в г. Санкт-Петербурге дома и участка земли у наследников Державина - 86000 руб.; первоначальное приспособление указанного дома под помещение РКДК и квартир 15000 руб.; в 1848-1854 гг. на перестройку того же здания РКДК - 165000 руб.; в 1864 г. на расходы по переводу Тельшевского р.-к. епархиального управления из г. Ворни в г. Ковно - 52000 руб.; на постройку дома для Могилевского р.-к. архиепархиального управления и кафедральной митрополитской р.-к. церкви в г. Санкт-Петербурге по I Роте 300000 руб.; кроме того, на этот предмет было отпущено из остатков от содержания р.-к. духовенства по смете МВД 80000 руб.; в 18781880 гг. на переустройство дома Санкт-Петербургского губернатора под помещение архиепархиальной р.-к. семинарии - 90000 руб., часть из которых была отнесена на остатки от содержания р.-к. духовенства в империи; в 1896-1897 гг. на расширение митрополитской р.-к. церкви в г. Санкт-Петербурге по I Роте 103000 руб., из них 18000 руб. были отнесены на остатки от содержания р.-к. духовенства по смете МВД; в 1900-1901 гг. на перестройку зданий РКДК и архиепархиального управления по Фонтанке и по I Роте и приспособление под семинарию - 250000 руб.; в 1884 г. возвращено по делу князя Радзивилла - 25200 руб.; в 1899 г. возвращено по судебному делу Трублаевича - 18400 руб.; в
1903 г. возвращено Луцкому еврейскому обществу по судебному делу - 40000 руб.; в 1906 г. возвращено графу Плятер-Зибергу по судебному делу - 143600 рублей. Итого на приобретение недвижимой собственности и прочие расходы - 1368830 руб., по судебным делам - 227200 руб., а всего расходов из капитала - 1596030 рублей [3, л. 225-226 об.].

В 1895 г. последовали существенные изменения в формах счетоводства и отчетности по капиталам РКДК: все процентные бумаги были сданы в Государственный банк на хранение и управление по особому соглашению с Государственным банком, а наличные деньги - на текущий счет в Государственный и Волжско-Камский банки. РКДК были составлены правила о счетоводстве и отчетности по капиталам, находившимся в ведении РКДК, и 1 июля 1895 г. правила эти были утверждены МВД. На основании означенных правил по доходам и расходам находившихся в ведении РКДК капиталов ежегодно составлялись сметы, которые и утверждались министром внутренних дел.

На 1 января 1908 г. наличность р.-к. вспомогательного капитала Российской империи состояла в процентных бумагах 4767235 руб. 50 коп., в наличных деньгах - 13842 руб. 63 коп., итого - 4781078 руб. 13 коп.; стоимость земли и постройки по нормальной расценке - 1640400 руб., в долгу по займу Варковской р.-к. церкви - 2387 руб. 24 коп., а всего - 6423865 руб. 37 коп.

Доход по вспомогательному капиталу р.-к. духовенства Российской империи на 1908 г. исчислялся в следующем размере: проценты с капитала, по текущему счету и возврат купонного налога ${ }^{7}$ - 199109 руб. 98 коп., аннуат и процентов по долговым суммам - 4659 руб. 9 коп., итого - 203769 руб. 7 коп. [3, л. 227] (табл. 1).

Таблииа 1

\section{Движение вспомогательного капитала р.-к. духовенства Российской империи} в 1826-1908 гг., руб.

\begin{tabular}{|c|c|c|c|c|c|c|}
\hline Капитал & 1826 г. & 1828 г. & 1837 г. & 1842 г. & 1864 г. & $\begin{array}{c}1908 \text { г. } \\
\text { (на } 1 \text { января) }\end{array}$ \\
\hline $\begin{array}{l}\text { В процентных бумагах и наличных } \\
\text { деньгах }\end{array}$ & 18080 & 34789 & 433834 & 1576214 & 2122971 & 4781078,13 \\
\hline Ценность недвижимых имений & - & - & - & - & - & 1640400 \\
\hline В долгу по займу & - & - & - & - & - & 2387,24 \\
\hline Итого & - & - & - & - & - & 6423865,37 \\
\hline
\end{tabular}

Примечание. Составлено по данным: [13, л. 227]. 


\section{ОТЕЧЕСТВЕННАЯ ИСТОРИЯ}

\section{Вспомогательный капитал}

\section{р.-к. духовенства Царства Польского}

28 августа 1889 г. последовало высочайшее соизволение на утверждение мероприятий относительно капиталов р.-к. духовенства в Царстве Польском. Причем были установлены как временные, так и постоянные капиталы упраздненных приходских, филиальных и других р.-к. церквей и монастырей, по обращении их в государственные процентные бумаги, препроводить в РКДК, для образования неприкосновенного вспомогательного капитала на нужды р.-к. церквей Царства Польского, от которого на будущее время расходовать лишь процент и не иначе как с разрешения МВД, по представлениям РКДК, как то было установлено для подобного капитала р.-к. духовенства Российской империи.

До 1897 г. все полученные по указанному капиталу проценты присоединялись к капиталу и обращались в процентные бумаги. С 1897 г. около половины процентов с капитала выдавались на строительные нужды р.-к. церквей и духовных учреждений. С 1905 г. на указанные проценты была отнесена часть пенсии чиновников, служивших в Царстве Польском по ведомству ДДДИИ и их семейств (около 1800 руб.), а с 1906 г. все проценты с капитала вносились в смету расходов: на строительные нужды р.-к. церквей и духовных учреждений до 11000 руб. в год и на пенсии в размере до 1800 рублей. К примеру, в июне 1908 г. из указанного капитала выдавались следующие суммы: дочери чиновника, служившего в Царстве Польском, Каменской - 300 руб., вдове и дочерям агента по духовным делам в г. Риме Сальвияти - 1045 рублей.

Кроме того, из вспомогательного капитала Царства Польского были осуществлены следующие выплаты: 1 июня 1900 г. и 15 марта 1901 г. последовало высочайшее соизволение на выдачу из упомянутого капитала заимообразно 35000 руб. на переустройство института св. Станислава в г. Риме, с возвратом этой суммы из доходов института по 1000 руб. в год; 29 июня 1907 г. последовало высочайшее соизволение на позаимствование из этого капитала 21000 руб. на переустройство Люблинской р.-к. духовной семинарии с тем, чтобы в течение 1908 г., 1909 г. и 1910 г. из остатков от содержания того же духовенства были уплачены, по расчету, как сумма, необходимая для приобретения реализованных РКДК процентных бумаг, так и наросшие на них за истекшее время проценты. Для выдачи указанного позаимствования было реализовано $4 \%$ ренты на номинальную сумму 29800 рублей.

На 1 января 1908 г. вспомогательный капитал р.-к. духовенства Царства Польского состоял: из процентных бумаг на номинальную сумму - 302487 руб. 50 коп., наличными деньгами - 3257 руб. 80 коп., итого 305745 руб. 30 коп.; из сумм, состоявших в долгу по займам на институт св. Станислава в г. Риме, -27048 руб. 63 коп. и на Люблинскую семинарию - 29800 руб. (ном. 4 \% рентою). Всего вспомогательного капитала, с суммами, отпущенными заимообразно, 362593 руб. 93 коп. Годовой доход с капитала на 1908 г. исчислялся в сумме 11566 руб. 50 коп. и процент по займу на Люблинскую семинарию I - 132 руб. 40 коп., итого 12698 руб. 90 коп. [3, л. 227 об.-228].

\section{Фундушевый капитал}

Еще до образования вспомогательного капитала р.-к. духовенства Российской империи, р.-к. митрополит С. Сестренцевич стремился к сосредоточению денежных сумм, принадлежавшим духовным учреждениям под названием фундушевых, в ведении РКДК, которая и должна была заботиться об обеспечении целости церковных фундушей. С 1817 г. некоторые фундушевые капиталы поступили на хранение в РКДК и были обращены в билеты государственных кредитных учреждений [2, с. 242]. В ее ведение представлялись и частными лицами суммы, завещанные и пожертвованные духовным учреждениям. В 1864 г. в РКДК хранилось фундушевых сумм в процентных бумагах около 45000 рублей. В 1875 г. последовало распоряжение, чтобы жертвуемые духовным учреждениям суммы представлялись на хранение в РКДК. В 1889 г. РКДК по поводу ревизии отчетов р.-К. духовных консисторий признала желательным, чтобы означенный порядок, в видах обеспечения церковных денежных сумм от растраты, что имело место в виленской р.-к. духовной консистории по делу Петрусевича, распространить и 
на фундушевые суммы, поступившие в прежнее время. На истребование от р.-к. духовных консисторий всех имевшихся в них фундушевых капиталов для хранения в РКДК последовало предложение МВД от 8 ноября 1889 г. за № 5482, а 22 марта 1893 г. - высочайшее повеление, согласно которому было установлено за правило, чтобы капиталы р.-к. духовных учреждений Российской империи, жертвуемые и отказываемые им на разные цели, хранились в РКДК, фондами этих учреждений, а также было предоставлено министру внутренних дел право определения порядка такового хранения, ведения капиталам счетов и употребления процентов с них или самих капиталов по назначению [6, № 9441; 11, с. 73].

1 сентября 1894 г. директор ДЛДИИ поручил чиновнику особых поручений при МВДдействительному статскому советнику Вашкевичу произвести дознание, по чьей вине произошло в РКДК упущение в несвоевременном предьявлении к оплате вышедших в тираж погашения процентных бумаг РКДК, чем был нанесен убыток ее капиталам, и истребовать объяснения по этому делу от бухгалтера РКДК коллежского советника Бржиского и его помощника титулярного советника Федоровича [3, л. 136].

В заведывании РКДК состояло к 1 сентября 1894 г. капиталов в процентных бумагах на сумму 5331414 руб., подробно обозначенных в нижеприведенной таблице 2. Из них передано было в апреле и мае 1894 г. для конверсии 4043450 рублей. В этом последнем числе Государственным банком Российской империи было обнаружено вышедших в тиражи погашения билетов на сумму до 662000 руб. и, сверх того, в капиталах, не подлежавших конверсии, оказалось, по их проверке, вышедших разновременно в тиражи (1892-1894 гг.), 46500 руб., так что неправильно полученные и недополученные по тиражным капиталам проценты составляли приблизительно убыток около 48000 рублей. Более точное определение цифры этого убытка было невозможно, за неполучением из банка окончательного расчета по обмену тиражных билетов на новые [1, с. 241].

Порядок хранения и ведения счетоводства по фундушевым капиталам был установлен общими правилами о хранении и управлении капиталами РКДК, утвержденными министром внутренних дел 1 июля 1895 года. По указанным правилам фундушевые суммы разделялись на следующие капиталы: постоянного хранения, проценты с которого два раза в год рассылались через р.-к. консистории по назначению (сам же капитал оставался неприкосновенным), и временного хранения, проценты с которого присоединялись к капиталу и обращались в процентные бумаги (капитал, по мере необходимости, с надлежащего разрешения, употреблялся согласно воле жертвователя или завещателя). На 1 января 1908 г. в наличности фундушевого капитала было: постоянного хранения - 1059945 руб. 33 коп. и временного хранения - 130784 руб. 69 коп., итого 1190730 руб. 24 коп. Годовой доход с них составлял 46325 руб. 82 коп. Указанный капитал принадлежал 600 отдельным духовным учреждениям, причем минимальные пожертвования составляли 10 рублей [3, л. 228 об.-229].

\section{Ремонтный капитал}

Ввиду поступавших представлений р.-к. епархиальных начальников о выдачи пособий на строительство и ремонт р.-к. церквей, министром внутренних дел в 1846 г. было всеподданнейше доложено, что хотя строительство и ремонт р.-к. церквей должны входить в обязанности прихожан, как собственная их потребность, но иногда по недостаточности прихожан или другим особым случаям было необходимо оказывать пособия, император высочайше повелеть соизволил выделить из вспомогательного капитала р.-к. духовенства 300000 руб. под названием «ремонтного капитала» с тем, чтобы проценты с него были исключительно употребляемы на вышеупомянутый предмет по собственному усмотрению РКДК в ссуду или, по особым уважениям, безвозвратно. Проценты с указанного капитала выдавались в виде безвозвратных пособий на основании поступавших представлений р.-к. епархиальных начальников. Впоследствии проценты распределялись РКДК ежегодно (за истекший год) между всеми р.-к. епархиями Российской империи на основании сведений, представленных из епархий, по мере необходимости, с утверждения министра внутренних дел. В 1906 г. министр внутренних делпредложение от 8 декабря 1906 г. за № 5790 признал целесообразным установить на этот предмет следующие правила: 


\section{Капиталы в процентных бумагах, состоявшие в заведывании РКДК}

(по состоянию на 1 сентября 1894 г.)

\begin{tabular}{|c|c|c|c|c|}
\hline \multirow[b]{2}{*}{ Название капиталов и процентных бумаг } & \multirow[b]{2}{*}{$\begin{array}{c}\text { Количество } \\
\text { по номи- } \\
\text { нальной } \\
\text { цене, руб. }\end{array}$} & \multicolumn{2}{|c|}{ Из них } & \multirow{2}{*}{$\begin{array}{c}\text { Приблизи- } \\
\text { тельный убы- } \\
\text { ток в недопо- } \\
\text { лучении про- } \\
\text { цента }\end{array}$} \\
\hline & & $\begin{array}{c}\text { передано } \\
\text { в конверсии } \\
\text { в апреле } \\
1894 \text { г. }\end{array}$ & $\begin{array}{c}\text { вышло } \\
\text { в тиражи } \\
1892- \\
1894 \text { гг. }\end{array}$ & \\
\hline \multicolumn{5}{|l|}{ I. Вспомогательный капитал по империи } \\
\hline 5 \% билеты Госбанка, выпуск 1860 г. & 62050 & & & \\
\hline 5 \% билеты Госбанка, выпуск 1861 г. & 3680950 & \multirow{4}{*}{3800800} & 639050 & до 44000 \\
\hline 5 \% облигациями Восточного займа 1878 г. & 34800 & & & \\
\hline 5 \% облигациями Восточного займа 1879 г. & 3000 & & & \\
\hline 6 \% непр.-доход. билеты гос. ком. пог. долг. & 83425 & & & \\
\hline 4 \% непр.-доход. билеты гос. ком. пог. долг. & 857 & & & \\
\hline 4 \% облигациями 2-го внутр. займа 1891 г. & 220200 & & 10000 & до 900 \\
\hline 4 \% облигациями 3-го внутр. займа & 40400 & & & \\
\hline 4 \% облигациями 4-го внутр. займа & 48200 & & & \\
\hline 5 \% закладные листы Виленского земского банка & 46000 & & & \\
\hline 4,5 \% облигации внутр. займа 1893 г. & 18900 & & & \\
\hline 4,5 \% облигации внутр. конс. жел.-дор. займа, 1-й выпуск & 16500 & & & \\
\hline 4,5 \% закладн. листы Гос. двор. зем. банка & 1800 & & & \\
\hline Серия гос. казначейства & 50 & & & \\
\hline Итого & 4277132 & & & \\
\hline \multicolumn{5}{|l|}{ II. Фундушевый капитал } \\
\hline 5 \% билеты Госбанка, выпуск 1860 г. и 1861 г. & 140800 & & & \\
\hline 5 \% билеты Восточного займа 1878 г. & 76800 & 217600 & до 23000 & до 1400 \\
\hline Непрерыв.-доход. билеты гос. ком. поч. долг. & 19992 & & & \\
\hline 5 \% закладные листы Виленского земского банка & 41400 & & 14500 & \\
\hline 5,5 \% закладные листы Херсонского земского банка & 3000 & & 2000 & до 700 \\
\hline 4 \% облигации 3-го и 4-го внутреннего займа 1891 г. & 114200 & & & \\
\hline $\begin{array}{l}4,5 \% \text { облигации внутреннего конс. железнодорожного } \\
\text { займа } 1890 \text { г. }\end{array}$ & 12900 & & & \\
\hline 5 \% билеты Госбанка с выигрышем & 400 & & & \\
\hline 5 \% облигации СПб гор. кред. общества & 17600 & & & \\
\hline Временное свидетельство на 4 \%-ю гос. ренту & 3000 & & & \\
\hline Разными другими процентными бумагами & 13360 & & & \\
\hline $\mathrm{C}$ & 443752 & & & \\
\hline \multicolumn{5}{|l|}{ III. Ремонтный капитал } \\
\hline 4 \% облигации 2-го внутреннего займа 1891 г. & 370500 & & 20000 & \\
\hline \multicolumn{5}{|l|}{ IV. Остатки по содержанию духов. в коллегиях } \\
\hline 5 \% облигации Восточного займа 1878 г. & 22100 & 22100 & & \\
\hline \multicolumn{5}{|l|}{ V. Вспомогательный капитал Царства Польского } \\
\hline $\begin{array}{l}4,5 \text { \% облигации внутреннего конс. железнодорожного } \\
\text { займа 2-го выпуска }\end{array}$ & 210400 & & & \\
\hline \multicolumn{5}{|l|}{ VI. Переходящие суммы } \\
\hline В разных мелких процентных бумагах & 7530 & 2950 & & \\
\hline 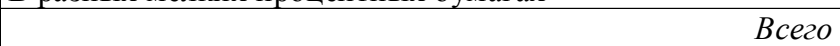 & 5331414 & 4043450 & 708550 & до 48000 \\
\hline
\end{tabular}

Примечание. Составлено по данным: [3, л. 140-140 об.].

1) проценты от ремонтного капитала, исчисляемые в ежегодно представляемой РКДК в МВД и утверждаемой им смете, употребляются на строительство и ремонт р.-к. церквей, когда по несостоятельности прихожан расходы эти не могут быть отнесены на их средства;

2) к 1 марта каждого года проценты от ремонтного капитала отсылаются в распоря- жение начальников 4-х нижепоименованных р.-к. епархий в следующих размерах: для Могилевской архиепархии - 5857 руб. 90 коп. и для Виленской, Луцко-Житомирской, Тельшевской р.-к. епархий - по 3100 руб.;

3) указанные суммы отпускаются р.-к. епископами по их усмотрению или в ссуду, или в безвозвратное пособие на строительные 
нужды р.-к. церквей, в израсходовании которых епископы представляют в РКДК, согласно п. 6 ст. 71 т. ХІ ч. 1 Уст. дух. дел., изд. 1896 г., ежегодный отчет с необходимыми оправдательными документами;

4) могущие образоваться в каждом году свободные остатки от произведенных расходов остаются в распоряжении начальников р.-к. епархий и составляют запасный фонд, употребляемый ими, в случае надобности, также на церковно-строительные нужды и подлежащий, наравне с ежегодными ассигнованиями, отчету перед РКДК.

Следует отметить, что в 1894 г. в силу конверсии и обмена 5 \% государственных бумаг на $4 \%$-ю ренту ремонтный капитал увеличился с 300000 до 374320 руб. 10 коп., годовой процент с которых составлял уже 15157 руб. 90 коп. [3, л. 229 об.-230] (табл. 3).

\section{Остатки от содержания \\ р.-к. духовенства}

\section{Самарской и Саратовской губерний}

Высочайше утвержденным 22 мая 1879 г. мнением Государственного Совета о передаче в ведение МВД заведывания сбором с поселян-собственников на содержание р.-к. духовенства - заведывание сборами с поселян-собственников и колонистов на содержание р.-к. духовенства было возложено на РКДК, а числившиеся в депозитах Министерства государственных имуществ капиталы, образовавшиеся из остатков от указанных сборов, решено было передать МВД.
В исполнение таковой высочайшей воли остатки от указанных сборов, в процентных бумагах и наличных деньгах, были переданы в РКДК (предложение министра внутренних дел от 13 июля 1879 г. за № 24231). В изменение существовавшего порядка взимания и расходования сбора с упомянутых поселян, предложением МВД от 30 ноября 1879 г. за № 3964 были установлены следующие правила: по составлении губернскими присутствиями раскладок сбора с наличного количества работников р.-к. исповедания в селениях бывших колонистов, таковые отсылаются в волостные правления для производства взыскания к 15 января; удовлетворение ежемесячным жалованием священников производится волостными правлениями; остатки от жалованья священников, образовавшиеся вследствие вакантных должностей, должны быть в конце года доставлены волостными правлениями в губернские присутствия, которые отсылают их в РКДК, для приобщения к остаточному капиталу; для проверки остатков Тираспольская р.-к. консистория сообщает РКДК ведомость за истекший год, с показанием времени, в течение которого поселенские приходы остались вакантными; расходы из процентов с этого капитала могут производиться лишь на выдачу пособий престарелым настоятелям приходов, достигшим 65 лет, не иначе как с разрешения МВД, по представлениям РКДК.

24 марта 1880 г. последовало высочайшее соизволение возложить на Тираспольскую p.-к. духовную консисторию наблюдение за поступлением сбора с р.-к. населения бывших

Денежный капитал, находившийся в управлении РКДК, руб. (по состоянию на 1 января 1908 г.)

\begin{tabular}{|l|c|c|c|c|c|}
\hline \multicolumn{1}{|c|}{\begin{tabular}{c}
\multicolumn{1}{|c|}{ кип } \\
капита
\end{tabular}} & $\begin{array}{c}\text { В процентных } \\
\text { бумагах и на- } \\
\text { личных деньгх }\end{array}$ & $\begin{array}{c}\text { В недвижимых } \\
\text { имуществах }\end{array}$ & $\begin{array}{c}\text { Выдано } \\
\text { заимооразно }\end{array}$ & $\begin{array}{c}\text { Всего } \\
\text { доходые } \\
\text { капиталов }\end{array}$ \\
\hline $\begin{array}{l}\text { Вспомогательный капитал } \\
\text { Российской империи }\end{array}$ & 4781078,13 & 1640400 & 2387,24 & 6423865,37 & 203769,7 \\
\hline $\begin{array}{l}\text { Вспомогательный капитал } \\
\text { Царства Польского }\end{array}$ & 305745,3 & - & 56848,63 & 362593,93 & 12698,90 \\
\hline Фундушевый капитал & 1190730,23 & - & - & 1190730,23 & 46325,82 \\
\hline Ремонтный капитал & 374320,1 & - & - & 374320,1 & 15157,9 \\
\hline $\begin{array}{l}\text { Капитал Самарской и Са- } \\
\text { ратовской губерний }\end{array}$ & 33753,73 & - & 34953,73 & 1291,25 \\
\hline \multicolumn{1}{|c|}{ Всего } & 6685626,64 & 1640400 & 60435,87 & 8386462,51 & 279242,94 \\
\hline
\end{tabular}

Примечание. Составлено по данным: [3, л. 232]. 
колоний Самарской и Саратовской губерний на содержание 12 воспитанников местной р.-к. духовной семинарии и передачу его в семинарию. Капитал, образованный из остатков от содержания р.-к. духовенства Самарской и Саратовской губерний, являлся неприкосновенным. До 1901 г. проценты, получаемые от этого капитала, не были расходуемы, а присоединялись к капиталу и обращались в процентные бумаги. В 1901 г. последовало высочайшее соизволение на выдачу из процентов от указанного капитала пожизненной пенсии канонику Флеку в сумме 400 руб. (в 1906 г. сумма увеличена до 500 руб. в год), в 1902 г. добавочной пожизненной пенсии епископу Церру - 500 руб. и в 1906 г. пенсии р.-к. священнику Довблису в сумме 240 руб. в год. В феврале 1899 г. (предложение министра внутренних дел от 4 февраля 1899 г. за № 438) было выдано Екатеринодарской р.-к. церкви заимообразно 3000 руб., с уплатой в течение 15 лет ежегодными взносами по 200 руб., без процентов. На 1 января 1908 г. в наличности указанного капитала процентными бумагами насчитывалось 33625 руб. и наличными деньгами - 128 руб. 73/4 коп., итого - 33753 руб. $73 / 4$ коп., в долгу по займу - 1200 руб., всего - 34953 руб. 73/4 коп. Проценты с капитала составляли в год 1291 руб. 25 коп., при расходах на выдачу пенсий в год 1240 рублей [3, л. 231-231 об.].

\section{Заключение}

Относительно вопроса сохранности и принадлежности вышеуказанных капиталов, после трагических событий 1917 г., следует отметить, что они не были потеряны для РКЦ. Доказательством тому может служить нижеприведенный документ.

13 сентября 1906 г. санкт-петербургской конторой Государственного банка Российской империи были приняты во вклады на хранение и управление принадлежавшие М.К. Жебревскому капиталы, завещанные им на благотворительные цели, в виде ценных бумаг 4,5 \% закладных листов московского земельного банка, номинальной суммой 2000 рублей. 1 августа 1928 г. ликвидационный комитет по делам российских земельных банков, головной офис которого находился в г. Вар- шава, принял решение о перерасчете 4,5 \% закладных бывшего московского земельного банка в закладные виленского земельного банка. Согласно обращению виленской р.-к. митрополии в ликвидационный комитет сумма в 3000 руб., с учетом процентов и перерасчетов по состоянию на 19 апреля 1934 г., была отнесена к пассивам бывшего московского земельного банка. Ликвидационный комитет постановил выплатить конверсией, согласно распоряжению министра сокровищ от 20 июня 1929 г., по 13,5 злотых за каждые 100 руб. 4,5 \% закладных по бумагам виленского земельного банка и по 19,10386 злотых соответственно московского земельного банка. К выплате, по состоянию на 1 августа 1928 г., в общем оказалось 570 злотых. Но деньги продолжали оставаться на депозите в 4,5 \% закладных виленского земельного банка. 14 мая 1938 г. виленский р.-к. архиепископ митрополит поручил управляющему канцелярией священнику А. Савицкому получить из виленского отделения Государственного краевого банка часть суммы в размере 299 злотых 30 грошей, назначенной виленской р.-к. курии по ликвидации бывших российских земельных банков [18, л. 12-13, 17-19].

Таким образом, инициатива в аккумулировании капиталов, принадлежавших РКЦ в Российской империи, исходила от представителей высшего р.-к. духовенства - управляющих РКДК, стремившихся к централизации и унификации в управлении церковью. Со временем функционирование капиталов, принадлежавших РКДК, было подчинено общим правилам управления финансами в империи, что не могло не вызывать нареканий со стороны духовной власти. Революционные события 1917 г. и последовавшие за ними перемены в жизни общества не привели к полной потере капиталов РКЦ, овеществленных, благодаря действиям правительства Российской империи, в денежной форме.

\section{ПРИМЕЧАНИЯ}

Альтария - производное от слова алтарь (лат. «altare», от «altus»- высокий). В христианском храме та часть, в которой находится престол [12, с. 56].

${ }^{2}$ Все суммы исчислены на серебро, а не на ассигнации. 
3 Фундуш (польский юридический термин, официально усвоенный и российским юридическим языком) - в старопольском праве обозначает дар в пользу какого-нибудь учреждения, чаще всего в пользу р.-к. церкви или монастыря. В источниках польского права упоминаются часто так называемые «Zapisy funduszowe» и «czynienie funduszów», то есть пожертвования. Впоследствии понятие «фундуш» распространилось на всякого рода имущества духовных учреждений, без отношения к источнику, из которого они происходили. Этим термином безразлично обозначалось как движимое имущество (капиталы), так и недвижимое. Когда имущества, принадлежавшие духовенству, получили иное назначение, выражения «фундуш», «имения фундушные» стали применять к имениям других общественных учреждений. Так, например, когда в 1773 г. Римский Папа Климент XIV уничтожил орден иезуитов, имения и капиталы, оставшиеся после них, были предназначены на цели общественного воспитания и получили специальное название: «fundusz edukacijny» (эдукационный капитал). Также под термином «духовные фундуши» объединялись наличные деньги и капиталы, принадлежавшие Римско-католической церкви, помещенные в банке и на ипотеке. Доходы от этих имений и «фундушей», названных «подуховными», предназначались на содержание р.-к. духовенства. Известен еще так называемый «стипендиальный фундуш», то есть капитал, проценты с которого были предназначены специально для помощи учащимся. Существовал еще и «эмеритальный фундуш», то есть эмеритальная (инвалидная, пенсионная) касса служащих в казенных и общественных учреждениях [17, с. 879-880].

4 Бенефиций (лат. «beneficium» от «bene»благо, добро и «facere» - делать) - термин, обозначающий различного рода юридические преимущества («beneficia juris»), то есть такие положения закона, на основании которых известным лицам, в известных случаях, предоставлялась возможность избежать некоторых неблагоприятных для них юридических последствий, которым без того они должны бы были подвергнуться в силу общих законодательных постановлений или юридической логики и толкования. В практике РКЦ бенефиции представляли собой духовные места, зависевшие от высшего местного духовенства и от короля. Согласно конкордату, заключенному между Сигизмундом I и Папой Львом X и подтвержденному в 1525 г. Папой Климентом VII, был установлен определенный порядок в раздаче бенефиций: Папы могли раздавать только такие бенефиции, которые были вакантны в нечетные месяцы года. На виленском синоде 1669 г. постановлено было давать бенефиции только уроженцам той р.-к. епархии, в которой собственно и находилась епархия. Кроме того, чтобы получить бенефицию, надо было иметь известный образовательный ценз. Бенефиции, как пожизненное владение, оставались на попечении бенефициата, который отвечал за все убытки. Он должен был стараться содержать все в исправности и отдать все бенефиции в лучшем состоянии, чем он получил ee [16, с. 434-435].

${ }^{5}$ Складочный капитал - это денежная оценка совокупности вкладов, которые были внесены участниками. Размер доли участника определялся в процентах, исходя из размера дохода участника. Доля в уставном капитале не определяла объем прав участника.

${ }^{6}$ Аннуата (от лат. «annus» - год) - пожизненный годовой доход, отданный в рост на вечные времена [12, с. 84]. Чаще всего люди, отдавая при жизни свои капиталы Римско-католической церкви, выговаривали себе или родственникам определенные условия: чтение литургии несколько раз в год, произношение молитв, обеспечение определенных духовных служителей жалованьем (например, осуществлявших духовное служение при р.-к. фамильной часовне) и т. д.

7 Купонный налог - налог на процентный доход по облигациям, рассчитываемый пропорционально количеству дней, прошедших от даты выпуска купонной облигации [разновидность облигации с промежуточными (купонными) выплатами, не уменьшающими ее номинальной стоимости] или даты выплаты предшествующего купонного дохода. Купон представлял собой часть облигации, которая отрезалась или отрывалась при выплате процентов или погашении ценной бумаги банком.

\section{СПИСОК ЛИТЕРАТУРЫ}

1. Ганчар, А. И. Аудит капиталов Римско-Католической Церкви в Российской империи (1894 г.) / А. И. Ганчар // Современные технологии сельскохозяйственного производства : сб. науч. ст. по материалам XX Междунар. науч.-практ. конф., г. Гродно, 12 мая 2017 г. - Гродно : Издательско-полиграфический отдел УО «ГГАУ», 2017. - 448 с. - (Экономика. Бухгалтерский учет. Общественные науки). - С. 240-241.

2. Ганчар, А. И. Рынок ценных бумаг в Российской империи / А. И. Ганчар // Современные технологии сельскохозяйственного производства : сб. науч. ст. по материалам XX Междунар. науч.практ. конф., г. Гродно, 12 мая 2017 г. - Гродно : Издательско-полиграфический отдел УО «ГГАУ», 2017. - 448 с. - (Экономика. Бухгалтерский учет. Общественные науки). - С. 242-243.

3. Дело о приобретении Римско-католической духовной Коллегией процентных бумаг и внесения 
в Государственный банк, обмене этих бумаг на процентные бумаги частных земельных банков и государственную 4 \% ренту. Ч. IV // Российский государственный исторический архив. - Ф. 821. Оп. 125. - Д. 543. - 239 л.

4. Канфесійны фактар у сацыяльным развіцці Беларусі (канец XVIII - пачатак XX ст.) / В. В. Яноўская [i інш.] ; навук. рэд. В. В. Яноўская ; Нац. акад. навук Беларусі, Ін-т гісторыі. - Мінск : Беларуская навука, 2015. - 496 с.

5. Лиценберг, О. А. Римско-католическая церковь в России : история и правовое положение / О. А. Лиценберг. - Саратов : Поволж. Акад. гос. службы, 2001.-384 с.

6. ПСЗРИ. Собрание третье. Т. 13 (1893). СПб. : Гос. тип., 1897.-708 с.

7. ПСЗРИ. Собрание второе. Т. 4 (1829). СПб. : Тип. ІІ Отделения Собственной Его Императорского Величества Канцелярии, 1830. - 968 с.

8. ПСЗРИ. Собрание второе. Т. 37 (1862). СПб. : Тип. ІІ Отделения Собственной Его Императорского Величества Канцелярии, 1865. - 832 с.

9. ПСЗРИ. Собрание второе. Т. 7 (1832). СПб. : Тип. ІІ Отделения Собственной Его Императорского Величества Канцелярии, 1833. - 1044 с.

10. ПСЗРИ. Собрание второе. Т. 36 (1861). СПб. : Тип. ІІ Отделения Собственной Его Императорского Величества Канцелярии, 1863. - 673 с.

11. Свод законов Российской империи. Т. XI, Ч. 1-я. Свод учреждений и уставов управления духовных дел иностранных исповеданий христианских и иноверных. Издание 1896 года. - СПб., [1896]. 174, XII c.

12. Словарь иностранных слов, вошедших в состав русского языка. Материалы для лексической разработки заимствованных слов в русской литературной речи / под ред. А. Н. Чудинова. - СПб. : Изд. книгопродавца В. И. Губинского, 1894. - 502 с.

13. Тихонов, А. К. Католики, мусульмане и иудеи Российской империи в последней четверти XVIII - начале XX в. / А. К. Тихонов. -СПб. : Изд-во С.-Петерб. ун-та, 2008. - 368 с.

14. Толстой, Д. А. Римский католицизм в России. Историческое изследование : в 2 т. / Д. А. Толстой. СПб. : Тип. В.Ф. Демакова, 1876-1877. - [578], 585 с.

15. Чихачев, Д. Н. К вопросу о располячении костела в прошлом и настоящем / Д. Н. Чихачев. СПб. : Тип. т-ва А. С. Суворина «Новое время», 1913. $-136 \mathrm{c}$.

16. Энциклопедический словарь : в 86 т. Т. III (5). Банки - Бергеръ / под ред. проф. И. Е. Андреевского ; издатели Ф. А. Брокгауз (Лейпциг), И. А. Ефрон (С.-Петербург). - СПб. : Семеновская Типо-Литография, 1891. - 480 с.

17. Энциклопедический словарь : в 86 т. T. XXXVIA (72). Франконская династия - Хаки / из- датели Ф. А. Брокгауз, И. А. Ефрон. - СПб. : Изд-е Брокгауз - Ефрона, 1902. - 956 с.

18. Akta Kurji Metropolitalnej Wilenskiej// Lietuvos mokslųakademijos biblioteka.-F. 318-26023.

19. Dzwonkowski, R. Polacy na dawnych kresach wschodnich. Z problematyki narodowościowej i religijnej / R. Dzwonkowski. - Lublin : Oddział Lubelski Stowarzyszenia «Wspólnota Polska», 1994. - $150 \mathrm{~s}$.

20. Kumor, B. Historia Kościoła: w 7 cz. / B. Kumor. - Lublin : Katolicki Uniwersytet Lubelski, 1973. - Cz. 7. $-514 \mathrm{~s}$.

21. Kumor, B. Ustrój i organizacja Kościoła polskiego w okresie niewoli narodowej. 1772-1918 / B. Kumor. - Kraków : Polskie Tow-wo Teologiczne, 1980. $-700 \mathrm{~s}$.

22. Lewalski, K. Kościoły chrześcijańkie w królestwie Polskim wobec żydów w latach 1855-1915 / K. Lewakski. - Wrocław : Fundacja na rzecz nauki Polskiej, 2002. - 348 s.

23. Nagrodzki, Z. Rola duhoweństwa katolickiego w godzinie prób i cierpiec na terenie Litwy i Białej Rusi (1863-1883) / Z. Nagrodzki. - Wilno : Znicz, 1935. $274 \mathrm{~s}$.

24. Petrani, A. Kollegium Duchowne w Petersburgu / A. Petrani. - Lublin : wyd. TN KUL, 1950. $-152 \mathrm{~s}$.

25. Radwan, M. Polityka wyznaniowa caratu na Białorusi w XIX w. Implikacje duszpasterskie/ M. Radwan // Nasza preszłość. -2001.-T. 95. -S. 197-240.

26. Stopikowski, R. Kościół katolicki w Cesarstwie Rosyjskim w świetle polskiej prasy katolickiej drugiej połowy XIX wieku / R. Stopikowski ; pod red. ks. E. Walewandra. - Warszawa : Stowarzyszenie współpracy Polska-Wschód, 2001. - 385 s.

27. Walicki, A. Rosja, katolicyzm i sprawa polska / A. Walicki. - Warszawa : Prószyński i S-ka, 2002.$312 \mathrm{~s}$.

\section{REFERENCES}

1. Ganchar A.I. Audit kapitalov RimskoKatolicheskoy Tserkvi v Rossiyskoy imperii (1894 g.) [Audit of the Capital of the Roman Catholic Church in the Russian Empire (1894)]. Sovremennye tekhnologii selskokhozyaystvennogo proizvodstva: sb. nauch. st. po materialam XX Mezhdunar. nauch.-prakt. konf., g. Grodno, 12 maya 2017 g. [Collected Articles of the $20^{\text {th }}$ International Research and Practice Conference "Modern Technologies of Agricultural Production" (Grodno, May 12, 2017)]. Grodno, GGAU Publ., 2017, pp. 240-241.

2. Ganchar A.I. Rynok tsennykh bumag v Rossiyskoy imperii [The Securities Market in the Russian Empire]. Sovremennye tekhnologii selskokhozyaystvennogo proizvodstva: sb. nauch. st. 
po materialam XX Mezhdunar. nauch.-prakt. konf., g. Grodno, 12 maya $2017 \mathrm{~g}$. [Collected Articles of the $20^{\text {th }}$ International Research and Practice Conference "Modern Technologies of Agricultural Production" (Grodno, May 12, 2017)]. Grodno, GGAU Publ., 2017, pp. 242-243.

3. Delo o priobretenii Rimsko-katolicheskoy dukhovnoy Kollegiey protsentnykh bumag i vneseniya v Gosudarstvennyy bank, obmene etikh bumag na protsentnye bumagi chastnykh zemelnykh bankov i gosudarstvennuyu $4 \%$ rentu. Ch. IV [Case on Acquisition of Interest-Bearing Securities by the Roman Catholic Clerical Collegium and Their Deposit in the State Bank, Exchange in Interest-Bearing Securities of Private Land Banks and the State 4\% Rent]. Rossiyskiy gosudarstvennyy istoricheskiy arkhiv [Russian State Historical Archive], F. 821, Op. 125, D. 543. 2391.

4. Yanouskaya VV., ed. Kanfesiyny faktar u satsyyalnym razvitstsi Belarusi (kanets XVIII pachatak XX st.) [Confessional Factor in the Social Development of Belarus (End of the $18^{\text {th }}-$ Beginning of the $20^{\text {th }}$ Century) ]. Minsk, Belaruskaya navuka Publ., 2015. 496 p.

5. Litsenberg O.A. Rimsko-katolicheskaya tserkov v Rossii: istoriya i pravovoe polozhenie [The Roman Catholic Church in Russia : history and the legal status]. Saratov, Povolzhskaya Akad. gos. sluzhby Publ., 2001. 384 p.

6. Polnoe sobranie zakonov Rossiykoy imperii. Sobranie tretye. T. 13 (1893) [Complete Collection of Laws of the Russian Empire. Vol. 13 (1893)]. Saint Petersburg, Gosudarstvennaya tip. Publ., 1897. 708 p.

7. Polnoe sobranie zakonov Rossiykoy imperii. Sobranie vtoroe. T. 4 (1829) [Complete Collection of Laws of the Russian Empire. Vol. 4 (1829)]. Saint Petersburg, Tip. II Otdeleniya Sobstvennoy Ego Imperatorskogo Velichestva Kantselyarii, 1830. 968 p.

8. Polnoe sobranie zakonov Rossiykoy imperii. Sobranie vtoroe. T. 37 (1862) [Complete Collection of Laws of the Russian Empire. Vol. 37 (1862)]. Saint Petersburg, Tip. II Otdeleniya Sobstvennoy Ego Imperatorskogo Velichestva Kantselyarii, 1865.832 p.

9. Polnoe sobranie zakonov Rossiykoy imperii. Sobranie vtoroe. T. 7 (1832) [Complete Collection of Laws of the Russian Empire. Vol. 7 (1832)]. Saint Petersburg, Tip. II Otdeleniya Sobstvennoy Ego Imperatorskogo Velichestva Kantselyarii, 1833. 1044 p.

10. Polnoe sobranie zakonov Rossiykoy imperii. Sobranie vtoroe. T. 36 (1861) [Complete Collection of Laws of the Russian Empire. Vol. 36 (1861)]. Saint Petersburg, Tip. II Otdeleniya Sobstvennoy Ego Imperatorskogo Velichestva Kantselyarii, 1863.673 p.
11. Svod zakonov Rossiyskoy imperii. T. XI, Ch. 1-ya. Svod uchrezhdeniy i ustavov upravleniya dukhovnykh del inostrannykh ispovedaniy khristianskikh $i$ inovernykh [The Laws of the Russian Empire. Vol. XI, Part 1. A Set of Institutions and Charters of Clerical Administration for Foreign Confessions of Christians and Heretics]. Saint Petersburg, [1896]. 174, XII $p$.

12. Chudinov A.N., ed. Slovar inostrannykh slov, voshedshikh $v$ sostav russkogo yazyka. Materialy dlya leksicheskoy razrabotki zaimstvovannykh slov $v$ russkoy literaturnoy rechi [Dictionary of Foreign Words, Included in the Russian Language. Materials for the Lexical Development of Borrowed Words in the Russian Literary Language]. Saint Petersburg, Izd. knigoprodovtsa V.I. Gubinskogo Publ., 1894. 502 p.

13. Tikhonov A.K. Katoliki, musulmane i iudei Rossiyskoy imperii $v$ posledney chetverti XVIII nachale $X X v$. [Catholics, Muslims and Jews of the Russian Empire in the Last Quarter of the $18^{\text {th }}$ - early $20^{\text {th }}$ Century]. Saint Petersburg, Izd-vo S.-Peterb. unta, 2008. $368 \mathrm{p}$.

14. Tolstoy D.A. Rimskiy katolitsizm v Rossii. Istoricheskoe izsledovanie: $v 2 t$. [Roman Catholicism in Russia. Historical Investigation: in 2 vols.]. Saint Petersburg, Tip. V.F. Demakova Publ., 1876-1877. [578], $585 \mathrm{p}$.

15. Chikhachev D.N. K voprosu o raspolyachenii kostela v proshlom i nastoyashchem [On the Church Location in the Past and Present]. Saint Petersburg, Tip. t-va A. S. Suvorina "Novoe vremya" Publ., 1913. $136 \mathrm{p}$.

16. Andreevskiy I.E., ed. Entsiklopedicheskiy slovar. Tom XIII. Banki-Berger [Encyclopedic Dictionary. Vol. 13. Banks - Berger]. Saint Petersburg, Semenovskaya Tipo Litografiya Publ, 1891. 480 p.

17. Andreevskiy I.E., ed. Entsiklopedicheskiy slovar: Tom XXXVIA. Frankonskaya dinastiya Khaki [Encyclopedic Dictionary. Vol. XXXVIA. The Franconian Dynasty - Hacks]. Saint Petersburg, tip. Akts. Obsh. Brokgauz-Efron Publ, 1902. 956 p.

18. Akta Kurji Metropolitalnej Wilenskiej [The Act of the Vilnius Metropolitan Curia]. Lietuvos mokslu akademijos biblioteka, F. 318-26023. 201.

19. Dzwonkowski R. Polacy na dawnych kresach wschodnich. $Z$ problematyki narodowościowej $i$ religijnej [The Poles on the Ancient Eastern Borders. With the National and Religious Problems]. Lublin, Oddział Lubelski Stowarzyszenia Wspólnota Polska, 1994. $150 \mathrm{p}$.

20. Kumor B. Historia Kościoła: $w 7$ cz. [History of the Church. In 7 vols.]. Lublin, Katolicki Uniwersytet Lubelski, 1973, vol. 7.514 p.

21. Kumor B. Ustrój i organizacja Kościoła polskiego w okresie niewoli narodowej. 1772-1918 [The Government and the Organization of the Church 


\section{ОТЕЧЕСТВЕННАЯ ИСТОРИЯ}

of Poland in the Period of National Captivity(1772-1918)]. Kraków, Polskie Tow-wo Teologiczne, 1980.700 p.

22. Lewalski K. Kościoły chrześcijańkie w królestwie Polskim wobec żydów w latach 1855-1915 [Church Chrześcijańkie in the Kingdom of Poland against the Jews in 1855-1915]. Wrocław, Fundacja na rzecz nauki Polskiej, 2002. 348 p.

23. Nagrodzki Z. Rola duhoweństwa katolickiego $w$ godzinie prób i cierpień na terenie Litwy i Biatej Rusi (1863-1883) [The Role of Catholic Clergy in the Hour of Trials and Sufferings in Lithuania and Belarus (1863-1883)]. Wilno, Znicz, 1935. 274 p.

24. Petrani A. Kollegium Duchowne w Petersburgu [Spiritual College in St. Petersburg]. Lublin, wyd. TN KUL, 1950. 152 p.
25. Radwan M. Polityka wyznaniowa caratu na Białorusi w XIX w. Implikacje duszpasterskie[Religious Policy of the Tsarist Regime in Belarus in the $19^{\text {th }}$ Century. The Consequences of Pastoral]. Nasza preszłość, 2001, vol. 95, pp. 197-240.

26. Stopikowski R. Kościól katolicki w Cesarstwie Rosyjskim $w$ świetle polskiej prasy katolickiej drugiej polowy XIX wieku [The Catholic Church in the Russian Empire in the Light of the Polish Catholic Press in the Second Half of the $19^{\text {th }}$ Century]. Warszawa, Stowarzyszenie współpracy PolskaWschód, 2001. 385 p.

27. Walicki A. Rosja, katolicyzm i sprawa polska [Russia, Catholicism and the Polish Case]. Warszawa, Prószyński i S-ka, 2002. 312 p.

\section{Information about the Author}

Andrey I. Ganchar, Candidate of Sciences (History), Associate Professor, Head of Department of Economic Theory, Grodno State Agrarian University, Tereshkovoy St., 28, 230008 Grodno, Republic of Belarus, gancharandre1@yandex.by, https://orcid.org/0000-0002-9485-8520

\section{Информация об авторе}

Андрей Иванович Ганчар, кандидат исторических наук, доцент, заведующий кафедрой экономической теории, Гродненский государственный аграрный университет, ул. Терешковой, 28, 230008 г. Гродно, Республика Беларусь, gancharandre1@yandex.by, https://orcid.org/0000-0002-9485-8520 